Razumova E. N

Doctor of Economics, Associate Professor of National Aviation University, Ukraine; e-mail:krazum@ukr.net

Kyrylenko $\boldsymbol{O} . \mathrm{N}$.

Doctor of Economics, Associate Professor of National Aviation University, Ukraine; e-mail:ons@ua.fm

Ihnatiuk $\boldsymbol{V} \cdot \boldsymbol{V}$.

Ph. D. in Technical Sciences, Associate Professor of National Transport University, Ukraine; e-mail: nikushek@ukr.net

Novak $\boldsymbol{V}$. $\mathrm{O}$.

Ph. D. in Economics, Professor of National Aviation University, Ukraine; e-mail:novakv.nau@gmail.com

\title{
STRATEGIC AREAS OF DEVELOPMENT THE RAILWAY INDUSTRY IN THE CONDITIONS OF EUROINTEGRATION PROCESSES
}

Abstract. The article develops and substantiates strategic directions of development of the railway industry in the conditions of European integration processes, which requires the adoption of fundamental decisions in changing the management system of the industry. On the basis of the analysis of the results of the railway transport, the reasons for reducing the profit of passenger traffic were determined, and the measures proposed to increase the efficiency of its activities, taking into account the current world trends in the organization of work of this type of transport. The main reason for the critical state of Ukrainian railways is that in the sector no structural reforms, which have been carried by European countries and most CIS countries. Failure to adopt, in the near future, the cardinal measures aimed at replacing outdated technical equipment, the system of transport management, tariff policy, may lead to the impossibility of ensuring the need for passenger and cargo transportation.

Keywords: strategy, transport, globalization, management system, railway industry, competition, tariff policy, competitive positions.

JEL Classification: L92

Formulas: 4; fig.: 2; tabl.: 2; bibl.: 12.

Разумова К. М.

д.е.н., доцент,

Начіональний авіачійний університет, Україна;

e-mail:krazum@ukr.net

Кириленко О.М.

д.е.н., дочент,

Національний авіаційний університет, Украӥна;

e-mail:ons@ua.fm

Ігнатюк В. B.

к.т.н., доиент,

Національний транспортний університет, Україна;

e-mail:nikushek@ukr.net

Новак В. $\boldsymbol{O}$.

к.е.н., професор,

Національний авіаиійнийо університет, Украӥна; e-mail:novakv.nau@gmail.com 


\title{
СТРАТЕГІЧНІ НАПРЯМКИ РОЗВИТКУ ЗАЛІЗНИЧНОЇ ГАЛУЗІ В УМОВАХ СВРОІНТЕГРАЦІЙНИХ ПРОЦЕСІВ
}

Анотація. В статті розроблено та обгрунтовано стратегічні напрямки розвитку залізничної галузі в умовах євроінтеграційних процесів, що вимагає прийняття кардинальних рішень у зміні системи управління даної галузі. На підставі аналізу результатів роботи залізничного транспорту були визначені причини зниження прибутку пасажирських перевезень та запропоновані заходи підвищення ефективності їх діяльності, з урахування сучасних світових тенденцій організації роботи даного виду транспорту.

Ключові слова: стратегія, транспорт, глобалізація, система управління, залізнична галузь, конкуренція, тарифна політика, конкурентні позиції.

Формул: 4; рис.: 2; табл.: 2; бібл.: 12.

Разумова Е. Н.

д.э.н., доиент,

Национальный авиационный университет, Украина;

e-mail:krazum@ukr.net

Кириленко О. $\mathrm{H}$.

д.э.н., дочент,

Национального авиационного университета, Украина;

e-mail: ons@ua.fm

Игнатюк В. В.

к.т.н., доцент,

Наџионального технического университета, Украина;

e-mail:nikushek@ukr.net

Новак В. A.

к.э.н., профессор,

Наџионального авиационного университета, Украина;

e-mail:novakv.nau@gmail.com

\section{СТРАТЕГИЧЕСКИЕ НАПРАВЛЕНИЯ РАЗВИТИЯ ЖЕЛЕЗНОДОРОЖНОЙ ОТРАСЛИ В УСЛОВИЯХ ЕВРОИНТЕГРАЦИОННЫХ ПРОЦЕСОВ}

Аннотация. В статье разработано и обосновано стратегические направления развития железнодорожной отрасли в условиях интеграционных процессов, что требует принятия кардинальных решений в изменении системы управления данной отрасли. На основании анализа результатов работы железнодорожного транспорта были определены причины снижения прибыли пассажирских перевозок и предложены меры по повышению эффективности их деятельности, с учетом современных мировых тенденций организации работы данного вида транспорта.

Ключевые слова: стратегия, транспорт, глобализация, система управления, железнодорожная отрасль, конкурениця, тарифная политика, конкурентные позиции.

Формул: 4; рис.: 2; табл.: 2; библ.: 12.

\begin{abstract}
The recovery of Ukraine's economy after a long-term economic crisis, the intensification of foreign trade as a result of the gradual opening of European commodity markets, as well as the global trend towards increasing mobility require a steady and efficient operation of rail transport [1 p. 7]. In Ukraine, it provides $83 \%$ of total cargo turnover and $38 \%$ of passenger traffic, and consumers expect from the railways European quality of service, reliability, speed and safety of transportation. Nevertheless, the railway industry has shown a negative dynamics in the last few years [8 p. 18-19].

The main reason for the critical state of Ukrainian railways is that in the sector no structural reforms, which have been carried by European countries and most CIS countries. As a result, the railway industry is working on old principles that do not correspond to the current world trends in the organization of rail transport, make its functioning ineffective and complicate further development, hampering revenues in the investment industry, and prevent cooperation with private companies [4 p. 39].
\end{abstract}


Literature review and the problem statement. Some issues concerning the solution of this problem are highlighted in the works of both domestic and foreign authors. [2, p. 34-36; 5 p. $479 ; 6$ p. 70 $72 ; 7$ p. $132 ; 8$ p. 202-205]. In particular, they are considering different directions for developing a strategy for the development of rail transport.

Research results. At this stage there is the question that needs to be solved to increase the efficiency of functioning the railway industry, taking into account future strategic development. First of all, its concerns the most profitable freight transportation on the basis of strong competition at the transport service market.

The importance of performing of named task explain that passenger transportation have influence on the development of country economy, its defense capability, and also on the strengthening on communication between countries, social level of population, development of tourism and culture. But, unfortunately, they can be unprofitable. The results of its work allow not only updating the rolling stock, modernize the wagon economy and other infrastructure, improve passenger service technologies, and also compensate for their costs. So the strategic directions of railway industry are the significant at this time in the conditions of implementing the Euro integration proceses.

To the main reasons, in our opinion, we can include the following: groundless "reform" and lack of support of the rail industry by the state, imperfection of the mechanism for managing the efficiency of passenger transport operations, reducing the mobility of the population and, consequently, the volumes of transportation; high degree of wear and tear of rolling stock and untimely updating of it, as well as modernization of infrastructure, low level of service and comfort of transportation, absence of rights in railways to regulate the level of tariffs for passenger transportation depending on the dynamics of demand, which leads to administrative restraint of tariffs with their simultaneous increase in fuel, electricity and other resources, is not a complete compensation from the budgets of losses for privileged transportation. All this led to a loss in the competition for passengers in some segments with its growth (especially with motor vehicles).

The solution of these problems was aimed at reforming the sector, which is currently being carried out in accordance with the State Target reform program. Strategic directions and goals of the development of rail transport are based on the provisions of the Transport Strategy of Ukraine for the period up to 2020, approved by the Decree of the Cabinet of Ministers of Ukraine dated 20.10.2010 No. 2174, and the State Target Program for Rail Transport Reform for 2010-2019, approved by the Resolution of the Cabinet of Ministers of Ukraine 16.12.2009 № 1390, as well as the obligations assumed in implementing the EU legislation within the framework of the Association Agreement, showd table 1.

Table 1

Strategic directions and goals of railway transport development, taking into account the European market model $\left.{ }^{*}\right)$

\begin{tabular}{|c|c|c|}
\hline № & Aims & Tasks \\
\hline 1. & $\begin{array}{c}\text { Creation a European model of railway } \\
\text { transportation market }\end{array}$ & $\begin{array}{c}\text { Defining the principles of activity at the market of } \\
\text { railway transportation taking into account } \\
\text { development the competitiveness between couriers }\end{array}$ \\
\hline 2. & $\begin{array}{c}\text { Reform of the system of state governance of } \\
\text { the industry and the formation of policy in } \\
\text { the field, increasing the efficiency of state } \\
\text { supervision (control) in rail transport }\end{array}$ & $\begin{array}{c}\text { To organize the powers of the state bodies that form, } \\
\text { implement policy in the railway transport, carry out } \\
\text { state supervision (control) }\end{array}$ \\
\hline 3. & $\begin{array}{c}\text { Improvement of tariff regulation, provision } \\
\text { of free pricing in competitive sectors of the } \\
\text { transport services market }\end{array}$ & $\begin{array}{c}\text { Implementation of a new system of state regulation } \\
\text { of tariffs for rail transport }\end{array}$ \\
\hline 4. & $\begin{array}{c}\text { Implementation of safety management } \\
\text { systems at railroad transport enterprises }\end{array}$ & $\begin{array}{c}\text { Implementation of the provisions of Directive } \\
\text { 2004/49/EC on rail safety in national legislation }\end{array}$ \\
\hline 5. & $\begin{array}{c}\text { Ensuring accessibility and improvement of } \\
\text { the quality of rail transport services, } \\
\text { including for passengers with disabilities }\end{array}$ & $\begin{array}{c}\text { Development of Standards (Indicators) } \\
\text { of Service Quality of Infrastructure (which will be } \\
\text { included in the Agreement between the State and the } \\
\text { Infrastructure Operator) }\end{array}$ \\
\hline 6. & $\begin{array}{c}\text { Development of international rail freight } \\
\text { corridors }\end{array}$ & $\begin{array}{c}\text { Strategic planning of railway infrastructure } \\
\text { development in the direction of sea ports }\end{array}$ \\
\hline \multicolumn{2}{|c}{ "s Sourse systematized by authors for [ 2, 10]. } \\
\hline
\end{tabular}


Creation of a European model of the railroad market should be based on the creation of a vertically integrated management system in the middle of a public joint stock company, taking into account the competitive positions of the industry. Companies should be created not by the territorial principle, but by the directions of activity [9 p. 41-42].

The given business model of the European model of PJSC "Ukrzaliznytsia" will be based on five business verticals: freight transport and logistics, passenger transportation, infrastructure, traction services, production and service, as presented in fig. 1. The corresponding companies are scheduled to be established in the period 2017-2019.

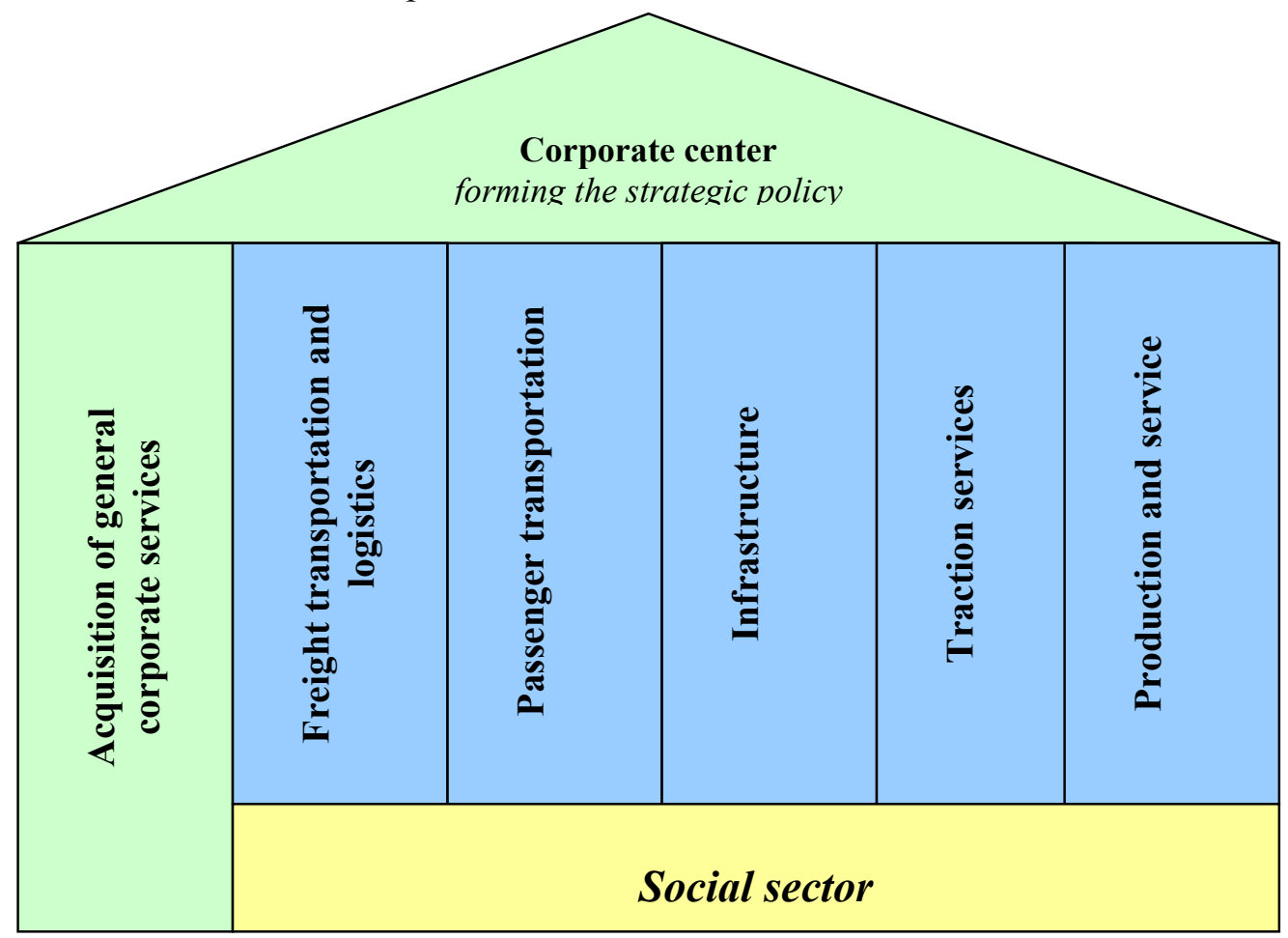

Fig. 1. Target business model of vertically-integrated development of PJSC "Ukrzaliznytsya"*)

${ }^{*}$ own authors' development.

In the freight transport sector, a transparent model of cooperation with shippers will be implemented. The second line of its activities is the expansion of services, which provides for the establishment of separate companies: territorial services, forwarding, contact logistics and intermodal transportation. It also provides for the creation of a company which specializes in the delivery of goods outside Ukraine. Taking into account these promising directions, by 2021, the market share of container transportation by railways has chances to increase from $29 \%$ to $45 \%$.

However, according to Razumova K.M., at each level of management of the industry it is necessary to assess the competitive advantages of business entities for passenger and freight transportation, which allows to define strategic goals and assessing the possibilities for their achievement, as presented in fig. 2. [4, p. 39; 11 p. 50-53].

This model represents the consistent implementation of measures ranging from the analysis of the market of transport services in the field of passenger transport and the definition of the internal capabilities of different modes of transport and ending with the implementation of the competitive advantages of different modes of transport in accordance with the basic strategy with the mandatory definition of strategic objectives and assessment of their ability to achieve $[6, \mathrm{p}$. 445-448; 10 p. 15].

First of all, for the development of international rail freight corridors, it is necessary to analyze the state of infrastructure in the directions of the international transport corridors and to identify the bottlenecks that can become a restraining factor for the transit of freight traffic. Particular attention should be paid to the strategic planning of railway infrastructure development in the direction of sea ports and the introduction of multimodal technologies. 


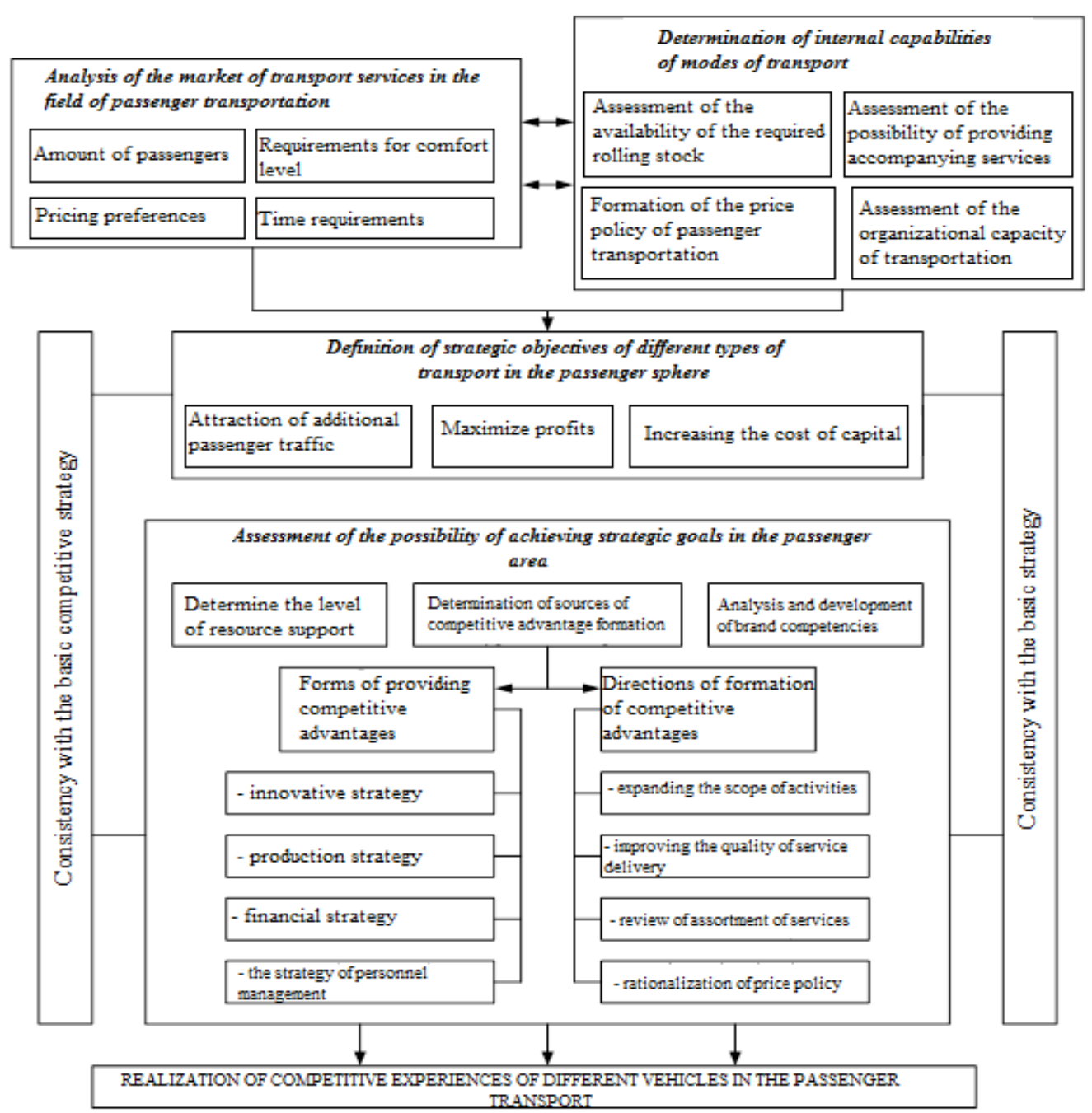

Fig. 2. Model of the competitive advantages of different types of transport in the field of passenger transportation*) ${ }^{*}$ own authors' development.

In accordance with the development strategy, from 2017 to 2021, upgrading the rolling stock will invest up to 108 billion UAH. Already in the first quarter of this year more than 1 thousand units. freight cars that more than the previous three years. By the end of 2021 it is planned to purchase 20 thousand new freight wagons.

A good result is also about the modernization of an existing park. According to the conducted researches, it was established that at the plan of 19 thousand cars in 2016, 30 thousand were repaired. For the next five years, there is a fundamental renewal not only of the fleet of freight cars. So 9 billion UAH will be aimed at the purchase of 400 passenger cars, 11 billion - for the purchase of electric trains, 3,5 billion - diesel trains [2 p. 116-117]. And more than 10 billion - for the modernization and repair of existing rolling stock. These investments will only be possible through the development of effective state support mechanisms .

In general, investments in the rail industry for five years will amount to 130-150 billion UAH. This will allow to fully meet the needs of the Ukrainian economy in rail transportation, and the industry to fulfill the priority plans for asset renewal.

According to the strategic development plan for 2017-2021, a separate company - a traction rolling stock operator.

But, in our opinion, now, taking into account the crisis situation of the passenger complex and the oligopolistic market of passenger transport, the implementation of the tariff policy for rail passenger traffic should be based on the results of marketing research, carried out by applying a systemic approach. The analysis of the results of such studies will allow us to comprehend the inquiries and predict the most likely reaction of potential passengers to marketing programs - on 
different types of marketing incentives and at the level of tariffs [5 p. 491]. Without this information, the development and implementation of marketing programs will be carried out at random.

This European approach to tariff policy makes it possible to clearly identify the components of the tariff and establish the relationship between price and demand, with a view to making effective management decisions in the future regarding the formation of tariff levels for passenger traffic..

State regulation of tariffs on railway transport should be carried out taking into account a considerable number of factors determining the functioning of transport in the conditions of a market mechanism of management in servicing various sectors of the economy and meeting the social needs of the population..

In carrying out market researches, it has been established that unevenness of passenger traffic in time considerably complicates the work of rail transport, requires the creation of significant reserves of traffic and freight capacity, labor, material and financial resources. Increasing uneven traffic causes the need for additional investment in capital and leads to increased transportation costs. In order to mitigate the negative impact of uneven passenger traffic in time on the economic activity of rail transport, measures aimed at reducing this unevenness, including through flexible tariff policies, need to be implemented. In order to reduce the unevenness of passenger traffic over time, it is advisable to introduce a European system of differentiation of tariffs for periods over a year [5 p. 491-492].

According to the proposed mechanism, the system of stimulation of sales to adjust the basic tariffs should first take into account fluctuations in demand for passenger traffic.

Based on the analysis of available passenger traffic and the need to equalize the demand for passenger traffic, in order to more accurately assess the dynamics of demand, we propose to establish the coefficients of its elasticity (coefficients of indexation of tariffs), depending on changes in pricing policy and indicators of service quality standards. The basis of the indexation was the time factor (the date of the trip), since demand for passenger traffic depends heavily on him, other factors of tariff change are secondary [5, p. 490; 12 p. 80-81].

In table 2 it is shown, calculated by us data on the dynamics of tariffs for passenger trains. The average weighted rate of indexation of tariffs is 0,971 , that is approximately equal to 1 , indicating compliance with the balance of interests of the carrier and passenger.

Table 2

Flexural adjustment coefficients for calendar periods on the Railway Transport of Ukraine ${ }^{*}$

\begin{tabular}{|c|c|c|}
\hline Period of departure of a train & Amount of days & Indexation index \\
\hline $01.01-20.01$ & 20 & 1,02 \\
\hline $21.01-31.01$ & 11 & 0,86 \\
\hline $01.02-29.02$ & 29 & 0,95 \\
\hline $01.03-31.03$ & 31 & 1,01 \\
\hline $01.04-27.04$ & 27 & 1,02 \\
\hline $28.04-08.05$ & 11 & 1,03 \\
\hline 09.05 & 1 & 0,8 \\
\hline $10.05-31.05$ & 22 & 1,01 \\
\hline $01.06-31.08$ & 92 & 1,07 \\
\hline $01.09-30.09$ & 30 & 1,02 \\
\hline $01.10-24.12$ & 85 & 0,93 \\
\hline $25.12-30.12$ & 6 & 1,1 \\
\hline 31.12 & 1 & 0,7 \\
\hline & &
\end{tabular}

Under this indexation, the cost of travel documents for all categories of cars (JI, compartment, spacecard, general, first, second and third classes of high-speed trains), except for commuter trains. 
In addition, the value of the ticket price and placardage is adjusted by the coefficients for calendar periods and days of the week. So, on Thursday and Saturday, the cost of travel is set at $10 \%$ of the base cost, and on Friday and Sunday - increase by $10 \%$. At registration of a travel document on electric trains Intercity + in the direction "round trip" and a discount of $10 \%$ of the cost of travel.

It is known that the demand for goods and services is related to their reciprocal value. Therefore, in order to reduce demand during periods of peak traffic, it is necessary to increase the fare, and to reduce it, in order to stimulate it during periods of decline, the fare is to be reduced. Thus, the coefficients for tariffs that increase their level should be used in periods when the intensity of rail passenger transport operations is higher than the average, and the factors reducing the level of tariffs - in periods with a lower intensity of passenger traffic. For an indicator characterizing the intensity of transport, it is advisable to use average daily passenger traffic. Thus, the direction of changing tariffs is given by the indexes, are determined by the formula $[10, \mathrm{p} .13$; 11 p. 108]:

$$
I_{i}=\frac{\sum H L_{i} / t_{i}}{\sum H L / T}
$$

where: $I_{i}$ - index of daily passenger traffic in $i$ calendar period, times;

$\sum H L_{i}$ - passenger traffic in internal traffic in $i$ calendar period, pass-km;

$t_{i}$ - duration $i$ calendar period, days;

$\sum H L-$ total annual passenger traffic in inland, pass-km;

$T$ - duration of the year, days.

If at $i$ calendar period index $I_{i}$ will be bigger unit, tariffs should be applied increasing factor, and if $I_{i}$ less than one - use a lowering factor. At the same time, the more $I_{i}$ Different from the unit, so it is necessary to adjust the tariffs to a greater extent.

Since the differentiation of tariffs for periods over a year does not aim to generate additional income, the calculated income, taking into account the application of coefficients, should be equal to the revenue from transport that will be received without their application. This condition is fulfilled if the average weighted passenger turnover coefficient is equal to units, that is, $[10$, p. 14 ; 11 p. 109]:

$$
\sum_{i=1}^{m} \frac{\sum H L_{i}}{\sum H L} \cdot k_{s . i}=1
$$

where: $k_{s . i}-$ tariff rate at $i$ calendar period, times.

In this case, it is necessary that the coefficients of tariffs are at a certain interval. The upper limit of this interval is normalized, and the lower one is determined on the basis of the restriction (2). Obviously, the highest value of the coefficient to the tariffs, which is equal to the upper limit of the interval, is established in the period for the largest value of the daily passenger turnover index $I_{i}$. Accordingly, the lowest value of the coefficient to the tariffs, which is equal to the lower limit of the interval, is established in the period for the lowest value of the daily passenger turnover index.

It is also advisable to focus on the fact that the system of coefficients to tariffs will satisfy the above conditions if they are determined by the formula [10, p. 15; 11 p. 109]:

$$
\begin{cases}k_{s . i}=I_{i}^{\log _{I_{\min }} k_{d v}} & \text { якщ̧о } I_{i}<1 \\ k_{s . i}=I_{i}^{\log _{I_{\max }} k_{u p}} & \text { якщ̧о } I_{i} \geq 1,\end{cases}
$$

where $I_{\min }$ - the least value of the index of daily passenger traffic, times;

$I_{\max }-$ the highest value of the daily passenger turnover index, times; 
$k_{d w}$ - the lower boundary of the coefficient interval to tariffs, times;

$k_{u p}$ - the upper boundary of the coefficient interval to tariffs, times.

At the same time the upper one $k_{u p}$ the limit of the interval of the coefficients to the tariffs is set as the norm, and the lower limit $k_{d w}$ is determined from the equation (which follows from limitation 2):

$$
\sum_{i=1}^{z} \frac{\sum H L_{i}}{\sum H L} \cdot I_{i}^{\log _{\min } x}+\sum_{j=1}^{p} \frac{\sum H L_{i}}{\sum H L} \cdot k_{s . j}=1,
$$

Where $z$ - the number of periods with lowering rates to the tariffs;

$x$ - unknown parameter - lower limit of interval of coefficients to tariffs, times;

$p$ - the number of periods with coefficients to tariffs that increase their level.

With, $z+p=m$.

Similarly to coefficients of tariff differentiation during the year, coefficients of differentiation of tariffs by days of the week can be determined.

The main factor affecting passenger transportation revenue is demand. Therefore, in order to ensure the efficient operation of passenger transport, it is necessary to envisage factors that motivate the decision of potential passengers for a trip. These include: consumer tastes, the number of consumers, incomes, prices for accompanying services, expectations of increased prices and revenues. In different markets, these factors manifest themselves in different ways. Given the monopolistic nature of the market in question, the factors "consumer tastes" and "prices for accompanying services transportation" "will not, or will be, to a very small extent affect the demand.

The "expectation of price increase" factor due to the specificity of transportation as a product that can not be accumulated can affect the demand for a very short period of time. The "number of consumers" factor for a given market is determined by the number of population, whose change for the period of time investigated was insignificant. At the same time, the income factor of the population has undergone enormous changes [7 p. 199-201].

Since the cost of a trip depends on the category of train and the type of car, then the average weighted trip price is important for determining the total demand. Information on the demand for transportation is necessary for forecasts of volumes of transportation and, accordingly, formation of the strategy of development of the passenger railroad complex.

According to the results of studies on the theory of elasticity, for most of the goods and services offered on the market, you can calculate the price elasticity factor and for the future to know what to expect from the price increase - whether consumers will accept such an increase or refuse this service.

Conclusions. Failure to adopt, in the near future, the cardinal measures aimed at replacing outdated technical equipment, the system of transport management, tariff policy, may lead to the impossibility of ensuring the need for passenger and cargo transportation and the emergence of crisis phenomena not only in the railway industry but also in other strategically important areas. with its branches of economy of Ukraine.

\section{Література}

1. Про транспорт: Закон України від 10.11.1999 № 232/94-ВР [Електронний ресурс]. - Режим доступу: http://zakon.rada.gov.ua/go/232/94-вр.

2. Gevko I. B. Operational Management: Training Manual / I. B. Gevko. - Kyiv : Condor, 2005. -228 p.

3. Ilienko O. Problems of world air transportation market globalization / O. Ilienko ; The international university of logistics and transport in Wroclaw // Logistics and transport. - 2013. - № 3 (19). - P. 65-73.

4. Kyrylenko O. M. Features of functioning railway low-traffic lines // Proceedings of the 12th International Scientific Conference «Modern management problems» (Kyiv, October 28, 2016). - P. 39-40.

5. Razumova E. N. Competitive Strategies of Railway Transport of Ukraine as an Essential Part of the European Integration. Science and Education Studies / E. N. Razumova, O. M. Kyrylenko, V. O. Novak, S. V. Petrovska // Stanford University Press. 2018. - 1 (29) (January - March). - Vol. VIII. - P. 479-492.

6. Gryfin R. Fundamentals of Management: Textbook / R. Gryfin ; V. Yatsura (Sc. Ed.). - Lviv: BaK, 2001. - 624 p. 
7. Новак В. О. Взаємодія аеропорту з транспортними підприємствами: організація та управління : монографія / В. О. Новак, І. В. Гордієнко, О. К. Катерна, В. В. Матвєєв, О. В. Ільєнко. - Київ : НАУ, 2012. - 277 с.

8. Vasilenko A. O. Production (operational) management / A. O. Vasilenko, T. L. Tkachenko. - Kyiv : CUL, 2003. -532 p.

9. The Future of European Rail / Marketforce and the ASI's 16th Annual Conference: Running the railways in a competitive climate: exploring the evolving industry landscape (16th \& 17th March 2011, Brussels) [Electronic resource]. - Retrieved from http://marketforce.eu.com/Conferences/TheFutureofEuropeanRail201111.

10. Разумова К. М. Проблеми і перспективи розвитку пасажирського комплексу залізниць України / К. М. Разумова, I. М. Аксьонов // Інформаційно-аналітичний журнал «Економіка. Фінанси. Право». - Київ : Аналітик, 2016. - № 11/2. C. $13-15$.

11. Разумова К. М. Системний економічний аналіз у менеджменті пасажирських перевезень : монографія / К. М. Разумова. - Київ : Кондор, 2014. - 240 с.

12. Razumova E. N. Assessment of competitive positions of the enterprises of passenger transport, taking into account loyalty strategic partners // Sciences of the National Aviation University «Problems of system approach in Economics».- - Kyiv: NAU, 2014. - № 50. - P. 79-82.

Стаття надійила до редакизї 24.10.2017

СРазумова К. М., Кириленко О. М., Ігнатюк В. В., Новак В. О.

\section{References}

1. Pro transport : Zakon Ukrainy vid 10.11.1999 № 232/94-VR [On Transport: Law of Ukraine dated November 10, 1999 № 232/94-VR]. zakon.rada.gov.ua. Retrieved from http://zakon.rada.gov.ua/go/232/94-вр [in Ukrainian].

2. Gevko, I. B. (2005). Operational Management: Training Manual. Kyiv : Condor.

3. Ilienko, O. (2013). Problems of world air transportation market globalization. Logistics and transport, 3 (19), 65-73.

4. Kyrylenko, O. M. (2016). Features of functioning railway low-traffic lines. Proceedings of the 12th International Scientific Conference «Modern management problems» (Kyiv, October 28, 2016), (pp. 39-40).

5. Razumova, E. N., Kyrylenko, O. M., Novak, V. O. Petrovska, S. V. (2018). Competitive Strategies of Railway Transport of Ukraine as an Essential Part of the European Integration. Science and Education Studies. Stanford University Press, 1 (29) (Vol. VIII), (pp. 479-492).

6. Gryfin, R. (2001). Fundamentals of Management. V. Yatsura ( Sc. Ed.). Lviv : Buck.

7. Novak, V. O., Hordiienko, I. V., Katerna, O. K., Matvieiev, V. V., \& Ilienko, O. V. (2012). Vzaiemodiia aeroportu z transportnymy pidpryiemstvamy: orhanizatsiia ta upravlinnia [Interaction of the airport with transport enterprises: organization and management]. Kyiv : NAU [in Ukrainian].

8. Vasilenko, A. O., \& Tkachenko, T. L. (2003). Production (operational) management. Kyiv: ZUL.

9. The Future of European Rail. (2011). Marketforce and the ASI's 16th Annual Conference: Running the railways in a competitive climate: exploring the evolving industry landscape (16th \& 17th March 2011, Brussels). - Retrieved from http://marketforce.eu.com/Conferences/TheFutureofEuropeanRail201111.

10. Razumova, E. N., \& Aksenov I. M. (2016). Problemy i perspektyvy rozvytku pasazhyrskoho kompleksu zaliznyts Ukrainy [Problems and prospects of development of the passenger complex of Ukrainian railways]. Informatsiyno-analitychnyy zhurnal «Ekonomika. Finansy. Pravo» - Information-analytical magazine «Economics. Finances. Right», 11/2, 13-15. Kyiv: Analyst [in Ukrainian].

11. Razumova, E. N. (2014). Systemnyi ekonomichnyi analiz u menedzhmenti pasazhyrskykh perevezen [Economic Analysis in Passenger Transportation Management]. Kyiv: Condor [in Ukrainian].

12. Razumova, E. N. (2014). Assessment of competitive positions of the enterprises of passenger transport, taking into account loyalty strategic partners. Sciences of the National Aviation University «Problems of system approach in Economics». 50, 79-82. Kyiv: NAU.

Received 24.10.2017

CRazumova E. N, Kyrylenko O. N., Ihnatiuk $V$. V., Novak V. O. 